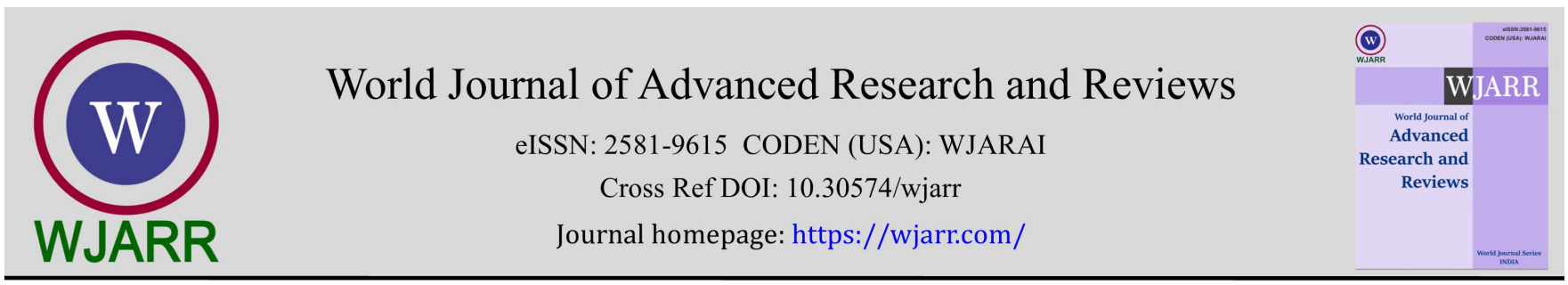

(REVIEW ARTICLE)

Check for updates

\title{
Arthur pendragon Camelot evolution in merlin: A virtual fan art in the computation age
}

\author{
Kwadwo Adinkrah-Appiah 1, Atianashie Miracle A 2, ${ }^{*}$, Chukwuma Chinaza Adaobi ${ }^{2}$ and Augustine Owusu- \\ Addo ${ }^{2}$
}

${ }^{1}$ Sunyani Technical University, Bono Region, Ghana.

${ }^{2}$ Catholic University College of Ghana, Fiapre Sunyani, Bono Region, Ghana.

World Journal of Advanced Research and Reviews, 2021,11(02), 040-047

Publication history: Received on 20 June 2021; revised on 30 July 2021; accepted on 02 August 2021

Article DOI: https://doi.org/10.30574/wjarr.2021.11.2.0340

\begin{abstract}
This paper inspects Arthur Pendragon Camelot evolution in Merlin, the research review on the Citadel of Camelot, Camelot Administration, Knights of Camelot, Early History of Camelot, The Intensification of The Once and Future King, Map of Camelot, and the Sovereignty of Arthur. Camelot Castle is the castle where the royal family live, and where the court is held. The citadel houses a garrison of at least 12,000 men and had never fallen in a siege before Morgause's invasion by her immortal army. It is currently the home of Guinevere Pendragon, the Queen of Camelot after her husband King Arthur Pendragon. In virtual fan art, Arthur Pendragon is shown to be a very wealthy kingdom as it offers a prize of a thousand gold coins for participation in its tournaments. Camelot is widely known for its laws banning all forms of magic and enchantments on penalty of death, usually by burning or beheading. However, the meter theater illustrates of Merlin who is Arthur's servant, secret protector, and best friend, and Gaius's ward and apprentice. Serves as an unofficial member of Arthur's Round Table and is a direct enemy of Mordred and Morgana. Waiting for Arthur to rise again. He is destined to protect Arthur so he can unite Albion under one high King.
\end{abstract}

Keywords: Camelot; Merlin; Arthur pendragon; Magic enchantments; Albion

\section{Introduction}

Camelot was a realm created by the mythical King Bruta in Albion. After the death of Ygraine Pendragon, magic was all but eradicated from the kingdom during the Great Purge. After being conquered by Uther Pendragon, it has been controlled by the Pendragon family. Camelot has become a legend in modern times. Its last known monarch was Queen Guinevere Pendragon, who, when her husband, King Arthur, died, likely reigned as Queen Regent. The citadel is a significant landmark of Camelot. The top section of the city is where craftspeople like Guinevere and her father, Tom the Blacksmith, used to dwell because it is closest to the castle. The Knights of Camelot visit a bar named The Rising Sun, which is located near the citadel. The lower sector is located on the city's outskirts and is home to the city's poorer classes. The bottom section was blocked off when Nimueh poisoned the water supply with the Afanc since here was where the majority of the casualties were (The Mark of Nimueh). Camelot organizes the Tournament of Camelot every year. Competitors go to the city from all five kingdoms to compete for a reward of 1000 gold pieces. [1].

\subsection{Citadel}

[2]. In the middle of the city is the castle where the royal family (Uther, Arthur, and Morgana) and the nobility live, and where the court is held. The castle is large and constructed of white brick. It has several tall towers and complex architecture and is considered Camelot's greatest asset in war as it is known to be virtually impregnable. Within the

\footnotetext{
${ }^{*}$ Corresponding author: Atianashie Miracle A

Catholic University College of Ghana, Fiapre Sunyani, Bono Region, Ghana.
} 
castle grounds are the quarters of the court physician, where Gaius and Merlin live. The citadel houses a garrison of at least 12,000 men and, before Morgause's invasion by her immortal army, had never fallen in a siege. It is currently the home of Guinevere Pendragon, the Queen of Camelot [3].

\subsection{Administration}

Camelot is an absolute monarchy that was ruled by Uther Pendragon who made all decisions until he was deposed by his traitorous daughter, Morgana, and her half-sister Morgause. Morgana, however, was soon overthrown by Merlin, Arthur, and his common-born knights (The Coming of Arthur). She later on conquered the kingdom with the help of southern warlord Helios, however, Arthur, later on, took back the kingdom once more [4].

Camelot is shown to be a very wealthy kingdom as it offers a prize of a thousand gold coins for participation in its tournaments and Agravaine stated many kings desire the wealth and power of the kingdom, this is also the reason that Cenred wished to conquer Camelot for its riches. Arthur Pendragon took over the kingdom as the Prince Regent when it became clear that Uther's spirit was broken by Morgana's betrayal. Arthur formally succeeded his father as king when Uther eventually succumbed to wounds dealt him by an assassin (The Wicked Day) sent by the vengeful King Odin. Camelot is widely known for its laws banning all forms of magic and enchantments on penalty of death, usually by burning or beheading. Such laws have been in place for more than twenty years, having been enacted during the Great Purge that followed the birth of Arthur and the subsequent death of Uther's beloved wife Queen Ygraine. These laws make Camelot, and Arthur specifically, the target of several attacks from rogue Warlocks and Witches, such as Nimueh, Morgause, and Morgana Pendragon who seek to avenge their murdered kin [5].

\subsection{Military}

Camelot is shown to possess a very powerful military led by the Knights of Camelot. Their coat of arms is a golden dragon on a red background. Knights and high-ranking officers wear red cloaks over their armour and archers seemed to be armed with crossbows. As said by Cenred, "...they have a reputation as a fearsome fighting force." Morgana also states that the Knights of Camelot are "...famed as the greatest knights in five kingdoms" (The Sword in the Stone, part 1) even Helios a great warrior himself stated without the Siege tunnel plans an attack on Camelot would be suicidal. Also, it was because of the Knights the kingdom did not fall to Cenred's army despite them being outnumbered two to one, however, this must be attributed to the fact that the knights are professionally trained and Cenred had a mostly mercenary army and the castles formidable defences. Because the kingdom fell to Morgause and Morgana's army, it can be assumed that most of Camelot's army was destroyed fighting the immortal army. They were replaced with the Blood Guards and Cenred's immortal army until Arthur and the Knights of the Round Table took back the kingdom and rebuilt their forces [6].

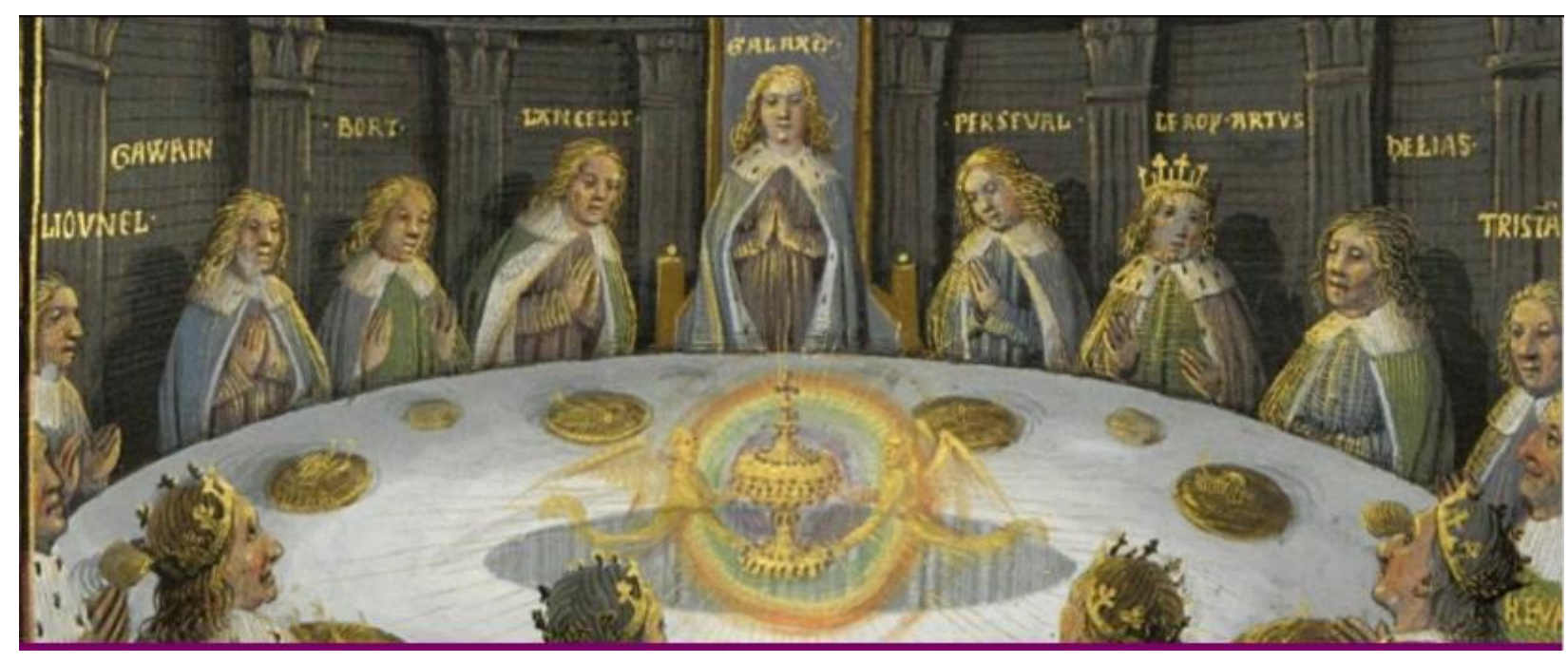

Figure 1 Knights of the kingdom of Camelot 


\section{Early History}

King Bruta was the first king of Camelot. It is said that the magic of Cornelius Sigan helped build Camelot. Later, Sigan became too powerful and the King at the time ordered him to be executed, however, Sigan devised a way to survive. 300 years ago, seven knights of Camelot betrayed the king and became a force of death and destruction serving the sorceress Medhir. They were only stopped when the sorceress herself was killed, as without her power to animate them, they became lifeless. Over 250 years later, the kingdom was conquered by Uther Pendragon who then became King of Camelot. Uther's new dominion of Camelot was allied with the kingdom of his old friend, Lord Godwyn. Gorlois was married to Vivienne and held a high position in the court of Camelot. Vivienne possessed a healing bracelet that was forged on the Isle of the Blessed. When Gorlois was away at battle, Vivienne had a brief affair with Uther Pendragon and conceived Morgana. She had Gorlois believe that he was the father of her second child. Gorlois raised Morgana, though it is unknown whether he knew of her true parentage. [7].

When Uther's wife, Ygraine, could not bear an heir to the throne of Camelot, Uther struck a bargain with the High Priestess Nimueh that would allow Ygraine to conceive. He appeared to have sent Gaius, who was the court sorcerer and physician, to the Isle of the Blessed to make the request on his behalf. Nimueh uses magic to allow Ygraine to conceive an heir. Unfortunately, Uther didn't know that by using magic to create a life, another life has to end in order to protect the natural balance of the world. As a result, Ygraine dies in childbirth. On the night of her death, Gaius saw the Questing Beast, a magical creature of the Old Religion and omen of misfortune. When Tristan's sister Ygraine died in childbirth, Tristan blamed Uther for her death and challenged him to a duel to the death. Uther won the duel but, before he died, Tristan swore that he would rise from the death and avenge Ygraine. Over the loss of his beloved wife, a grief-stricken Uther turns on Nimueh, accusing her of treason and banishing her from Camelot and began the Great Purge, ordering the executions of hundreds of sorcerers, good and evil. the Knights of Camelot hunted down and killed anyone using magic in Camelot. At the start of the Great Purge, Uther gave Gaius a list of all people suspected of using Magic to be killed; when Gaius discovered his beloved Alice on the list, he struck her name off, thus giving her time to escape [8].

Gaius decided to stop practicing magic and to remain in Camelot as court physician. At some point, Gorlois befriended Queen Annis and possibly King Caerleon. Alvarr's parents were captured by Uther's forces and were burned at the stake (apparently Alvarr witnessed this happen). He was sentenced to death as well, but shortly before his execution, whether by magic or non-magical means, he escaped and fled from Camelot. Jaden Muirden and her husband suffered this fate, they were sentenced to be burned at the stake. When they were being burned, Edwin tried to save his parents, remaining disfigured by the fire. Uther, during the Great Purge, hunted almost all Blood Guard and killed them. Julius Borden was a pupil of Gaius, having disappeared during the Great Purge and causing Gaius much trouble. The Crystal of Neahtid was kept and guarded by the High Priestesses on the Isle of the Blessed too before it was taken by Uther and locked into the vaults of Camelot. Uther also pursued and slaughtered all Dragons except for Kilgharrah, the Great Dragon. Uther tricked one dragonlord, Balinor, to lure the Great Dragon to Camelot under the pretense of wanting to make peace with it, only to capture and imprison the dragon beneath Camelot and then had all the Dragonlords rounded up and killed. Gaius helped Balinor to escape execution and chose to hide Balinor with his friend Hunith. Gaius' actions would lead Balinor to consider him a great man. During his time with Hunith, Balinor fell in love with her and unbeknownst to him had fathered a child with her. But when Uther came after him again, he was forced to leave Hunith behind. Hunith later gave birth to their son, Merlin. Uther sent Gorlois into battle and promised him reinforcements. However, Uther failed to send the reinforcements, resulting in Gorlois' death. Uther promised Gorlois that he would look after Morgana and subsequently readopted her as his own daughter. At some point in the past, war broke out between Caerleon and Camelot. He was defeated by Uther at the Battle of Denaria, but he retreated to the Castle of Fyrien. Victory would have been denied to Camelot if Uther hadn't known of a secret labyrinth beneath the castle. Camelot fought a long war against the kingdom of Mercia [9].

\section{The Intensification of The Once and Future King}

20 years after Arthur's birth, a young Warlock named Merlin was sent by his mother to Camelot to be taken care of by her friend Gaius, who was the court physician. Merlin's arrival was at the time a sorceress called Mary Collins attempted to assassinate Arthur after Uther executed her son. Merlin foiled this attempt and became Arthur's manservant. After years in hiding, Nimueh returns to wreak revenge, first using an Afanc to contaminate Camelot's water supply and later attempting to disrupt the end of hostilities between Camelot and Mercia [10].

Merlin tries to meddle with rules so that Lancelot, who saved him from a Griffin attack, can become a Knight. After the Griffin is killed and Arthur and Uther argue about Lancelot's right to be a Knight, Lancelot doesn't want to lie anymore and leaves Camelot. When Cornelius Sigan sent animated Gargoyles to attack Camelot, Arthur led his knights to hunt 
the creatures down and kill them. The battle didn't go well, Arthur was injured and several knights were killed, the attack was averted when Merlin defeated Sigan. Morgause later awoke the Knights of Medhir to kill Uther. She also approached Morgana and got her on her side. She then placed a spell upon Morgana, binding her life to a sleeping spell that she placed on Camelot and attack of Camelot. When The Great Dragon was released and attacked Camelot, Arthur led his men in an assault on him, Arthur was injured and many knights were killed, Merlin was able to stop him [11].

One year later, Morgana was found and returned to Camelot. Secretly, she was loyal to Morgause and turned Uther insane using an enchantment. Although he was later healed, Morgause convinced King Cenred to attack Camelot. Even with his army massed up to twenty thousand, they were no match for Camelot's garrison which was only half the size. Morgana resurrected the dead warriors of Camelot so the current warriors would be facing a battle on two fronts, however, Merlin defeated her and stopped the undead army, forcing Cenred to retreat. Eventually, Uther's anti-magic regime fell to Morgause and Morgana. Morgause turned the army of Cenred immortal, killed its king, and launched a successful invasion of Camelot. The city fell and Uther was captured. The former king was then forced to watch Morgana take the throne. However, Arthur along with Merlin managed to save Camelot from Morgana's rule. Merlin managed to destroy the immortal army, allowing Arthur to rescue Uther while Morgana was forced to escape with Morgause who was defeated by Merlin. At some point over the following year, Morgana allied herself with Arthur's uncle, Agravaine, who went to Camelot to support Arthur, as Uther was shaken by Morgana's betrayal to rule. Another year later, Morgana attempted to take revenge on Camelot again by summoning creatures known as the Dorocha. As a sacrifice was needed to defeat the Dorocha, Lancelot sacrificed himself. Uther was mortally wounded by an assassin when protecting Arthur and despite attempts to save him, eventually died. Arthur was crowned King of Camelot after his death [12].

\section{Sovereignty of Arthur}

Shortly afterwards, Odin commenced a series of raids on Camelot's northern borders. Following the death of Uther, Caerleon began raiding Camelot. During one of these raids, he was eventually led into a trap and captured. Following his uncle Agravaine's advice, Arthur tried to force him to sign a treaty. He refused, which made Arthur ordered him killed. His body was returned to his kingdom. This event led to the brief war between Camelot and his land, led by his wife. A Lamia starts to cause havoc and Merlin, Gwen and the Knights of the Round Table are sent in to investigate. Arthur proposes marriage to Guinevere in which she accepts and a jousting match is held. Morgana resurrects Lancelot to come between Arthur and Gwen after these events, Gwen is exiled. Elyan becomes possessed by a spirit of a Druid boy who was killed on Arthur's orders many years before and is commanded to kill the young king [13].

Morgana allies herself with Helios and Agravaine steals the siege plans from Camelot's vaults. Gwen alerts Merlin to this and he informs Arthur of the coming siege. Morgana with Helios and Agravaine's help invades Camelot and yet again becomes its Queen while Merlin and Arthur are forced to flee leaving their closest friends behind in Camelot. While on the run they encounter Tristan and Isolde and their fellow smugglers. Arthur and Gwen are reunited in Ealdor but along with Merlin are forced to flee. After a lengthy battle, Arthur regains the throne and makes Gwen his wife and queen. Three years of Camelot being ruled fairly by King Arthur and Queen Gwen, Gwaine, Percival and a mass of knights go missing leading Arthur and Merlin to go looking for them. Arthur summons the spirit of his father but Uther's spirit seeks to destroy everything Arthur has built [14].

Morgana allies with King Odin and takes off the Kingdom of Nemeth, capturing Princess Mithian and her father King Rodor and try to lure Arthur to his death. Eventually, a peace treaty between Arthur and Odin is formed. The Disir pass judgement on Arthur who doesn't accept magic. Mordred is wounded but recovers as punishment for Arthur from the Disir. Queen Guinevere is kidnapped by Morgana. Arthur, Merlin and the Knights journey to the Dark Tower where she is held captive which leads to Sir Elyan's death. Guinevere allies with Morgana. Morgana and Queen Guinevere twice attempt to assassinate Arthur however they are stopped by Merlin the Sarrum of Amata arrives in Camelot to sign a peace treaty. Here, he allies with Gwen and plans the Kings death; however, they are stopped by Merlin and the Sarrum is accidentally killed. Arthur and Merlin with the help of Mordred cleanse Guinevere at the Cauldron of Arianhrod where she is released from Morgana's hold. Morgana attacks the High Priest Alator of Catha and kidnaps him in order to learn of Emrys is real identity, Alator refuses to divulge his identity and she kills Alator after learning of his servant Finna who later on kills herself. Morgana officially declares war on Camelot via the warning of Ragaid on a Camelot Knight [15].

Sir Mordred turns against Camelot after his old love the Saxon Kara is killed for plotting to murder the King and allies With Morgana and the Saxons and reveals Merlin's magic. Morgana drains Merlin of his magic by using the fearsome creature the Gean Canach. The garrison at Stowell on the northern border is attacked and only a handful of Knights and a woman named Eira escape. Arthur declares that the Knights of Camelot will face the Saxon army at the pass of Camlann in the White Mountains to finally defeat Morgana. Merlin regains his magic at the Crystal cave and goes to the Battle of Camalann. Merlin arrives in his ultimate form of Emrys and defeats the combined Saxon force and Aithusa allowing 
Camelot a decisive victory. Mordred succeeds in fatally wounding Arthur who kills him in return, he is later on buried by Morgana who swears revenge. Merlin reveals his magic to Arthur and they travel to the Lake of Avalon to heal Arthur. Arthur gives the royal seal to Gaius to give to Guinevere. Eira is exposed as the traitor and executed, Sir Gwaine and Percival locate Morgana, however she overpowers them and tortures Gwaine to death with a Nathair. Morgana finds Arthur and taunts him over his impending death; however, she is killed by Merlin using Excalibur. Arthur succumbs to his wound and dies in Merlin's arms; Queen Guinevere becomes the sole ruler of Camelot [5].

\section{Maps of Camelot}
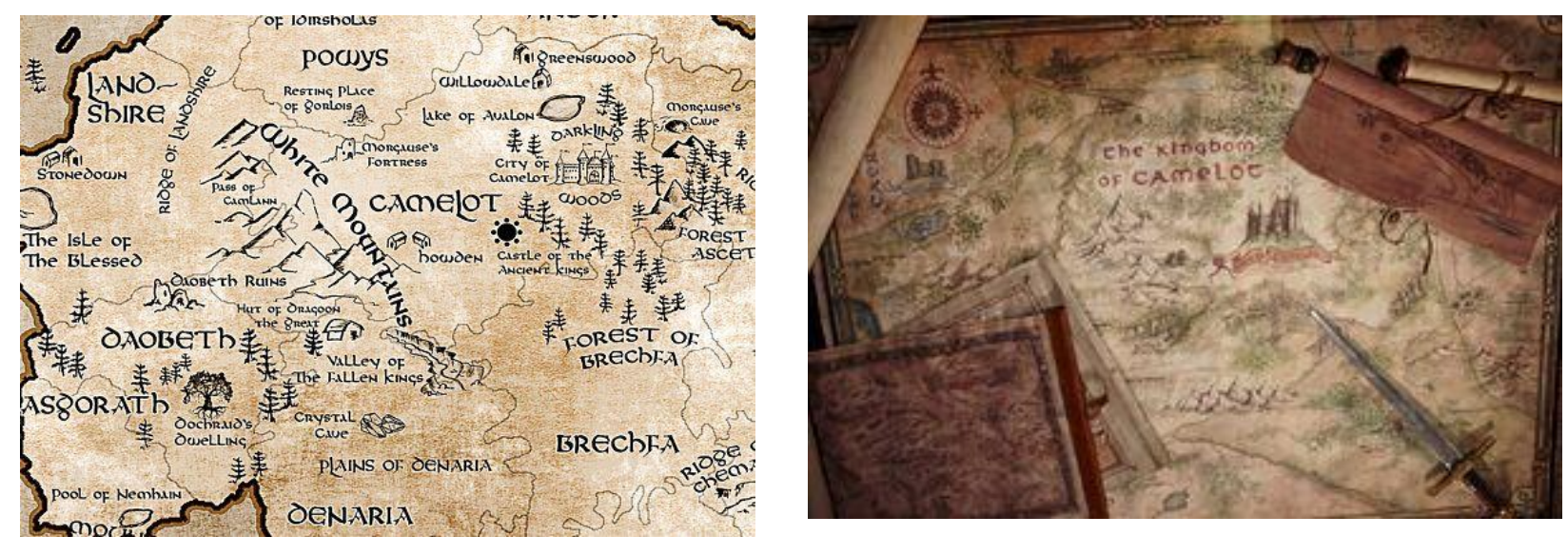

\section{Individuals of Importance in Camelot}

\subsection{Former King Uther Pendragon}

Former king of Camelot was removed from Throne, unfit to rule as a result of Morgana's treachery and died when protecting Arthur from an assassin sent by King Odin.

\subsection{Former Queen Ygraine Pendragon}

Former Queen of Camelot, alongside Uther Pendragon. Unable to conceive naturally, resulting in Uther asking Nimueh for assistance, possibly against Ygraine's knowledge. She died in childbirth to keep the life-and-death balance even, resulting in the Great Purge.

\subsection{Former King Arthur Pendragon}

Former Prince and later King of Camelot, became king after Uther died, husband of Queen Guinevere, brother-in-law of Sir Elyan and male best friend of Merlin. Died due to a fatal wound inflicted by his former good friend Sir Mordred, waiting to rise again.

\subsection{Queen Guinevere Pendragon}

Morgana's former best friend and former maidservant. She is the wife of King Arthur and the current Queen of Camelot, sister of the late Sir Elyan and female best friend of Merlin. Alongside Merlin and Gaius, is an unofficial member of the Round Table and serves as one of her husband's main confidants. She becomes Arthur's heir upon her husband's death at Mordred's hand as she and Arthur had not yet had children of their own when he died.

\subsection{Former Lady Morgana Pendragon}

Ward, secret daughter of Uther, later Queen, deposed Uther. Uther's secret Daughter as a result of an affair with her mother, Vivienne, whilst Gorlois was away. Though illegitimate, she believed she was entitled to the throne. She struggled to gain loyalty from the people of Camelot during her two reigns. Later she escaped Camelot with half-sister, Morgause and later plotted against Camelot. Eventually killed by her archenemy Merlin, using Excalibur. 


\subsection{Vivienne}

It was a Lady of Camelot and the wife of Gorlois, with whom it is likely she had a daughter called Morgause. When Gorlois was away at battle, Vivienne had a brief affair with Uther Pendragon and conceived Morgana. She had Gorlois believe that he was the father of her second child. It is likely that he never found out about his wife's affair. Vivienne was most likely a witch and had passed on her magical powers to her two daughters.

\subsection{Sir Tristan de Bois}

It also known as the Black Knight was the brother of Ygraine and Agravaine de Bois, the brother-in-law of Uther Pendragon, and the uncle of Arthur Pendragon.

\subsection{Sir Agravaine de Bois}

It was the brother of Ygraine and Tristan de Bois the brother-in-law of Uther Pendragon and the uncle of Arthur Pendragon. After Uther was mentally broken by Morgana's betrayal, Agravaine acts as Arthur's advisor, though he is secretly in league with Morgana, he was killed by Merlin after discovering his secret.

\subsection{Gorlois}

It was Uther Pendragon's best friend and the husband of Vivienne, possible father of Morgause and beloved stepfather to Morgana. Killed in Battle.

\subsection{Merlin}

Arthur's servant, secret protector and best friend and Gaius's ward and apprentice. He is also the best friend of Arthur's beloved wife, Guinevere. He is destined to protect Arthur so that he can unite Albion under one high King. Serves as an unofficial member of Arthur's Round Table and is a direct enemy of Mordred and Morgana. Waiting for Arthur to rise again.

\subsection{Gaius}

Court Physician, former follower of the Old Religion and sorcerer. He was also an advisor to Uther Pendragon and the guardian and father-figure of Merlin. He is also a member of the Court of Camelot and serves as an unofficial member of Arthur's Round Table alongside Merlin and Queen Guinevere. Later on, became Guinevere's mentor after Arthur death.

\subsection{Morgause}

A powerful sorceress and Morgana's beloved maternal half-sister and lieutenant, sacrificed to the Cailleachs after being fatally injured by Merlin.

\subsection{Edwin Muirden}

Former Court Physician, attempted to kill Uther (deceased).

\subsection{Lady Catrina}

Briefly Queen, deceased. True form was a troll.

\subsection{Nimueh}

High Priestess of the Old Religion and former friend to Uther. She allowed Ygraine to conceive an heir, though she didn't know a life (Ygraine's) would be taken. She was killed by Merlin when the life-and-death balance was again upset, threatening Arthur's life.

\subsection{Knights of Camelot}

The original knights of Camelot were defeated by Uther Pendragon when he conquered Camelot. His men then became the new Knights of Camelot. 


\subsection{Knights of the Round Table}

This are an elite order of knights, created by Arthur Pendragon during Morgana's first reign.

\subsection{Mordred}

Former Knight of Camelot and trusted friend of King Arthur Pendragon. Due to past events is an enemy of Merlin. Turned traitor and ally of Morgana when Arthur killed Kara. Killed Arthur at the battle of Camalann who in return killed Mordred.

\subsection{Geoffrey of Monmouth}

Court Genealogist and keeper of the royal library. He also hosts important events such as the wedding of Uther and Catrina and Arthur's coronation. He is a good friend of Gaius.

\section{Conclusion}

Camelot is the most famous castle and court in the Arthurian Legend. It was first mentioned in Chrétien de Troyes's The Knight of the Cart, and located at Caerleon, in Wales. It's Thomas Malory, in Le Morte d'Arthur, who, then first, identifies Camelot with Winchester, which is most familiar to English speakers today, as Thomas Malory's compilation remains the main reference of Arthurian legend. The most notable people there are King Arthur, Merlin, Uther Pendragon, Ygraine, Guinevere and Morgana le Fay. Even though it is said that Caerleon is Arthur's castle, Camelot is the one castle that is mentioned the most. Later, the British cleric Geoffrey of Monmouth (c. 1095 - c. 1155) would describe Camelot in his pseudohistory literary work Historia Regum Britanniae ("The History of the Kings of Britain"), as the center of the Kingdom of Logres, which he claimed was named after the legendary king Locrinus. The name "Logres" is derived from the Welsh word Lloegyr, referring to England (called Lloegr in Modern Welsh). Most often in the context of the Arthurian legends, the kingdom of "Logres" is used to describe the Brittonic territory roughly corresponding to the borders of England before the area was taken over by the Anglo-Saxons.

\section{Compliance with ethical standards}

\section{Acknowledgments}

Thanks to Prof. David Ugal for proper review of our paper to increase clarity and scholar quality

\section{Disclosure of conflict of interest}

The authors declare that there is no conflict of interest regarding the main research, authorship and publication of this paper.

\section{References}

[1] Álvares C. Qu'est-ce qui coule dans les veines? Arthur enfant (re) trouvé dans la série télévisée Camelot. 2021.

[2] Binder C, die Bräuerin A, Nationalbibliothek Ö. (n.d.). Albéniz, Isaac: Merlin. Opera in three acts [Libretto]. In: Ders.: Merlin. CD Decca 467 096-2.[Booklet], London 2000, S. 50-125. Alighieri, Dante: Die Göttliche Komödie. Italienisch und Deutsch. Übersetzt und kommentiert von Hermann Gmelin. 6 Bde., München 1988 [zuerst 1954]. Allfeld, Philipp: Wieland der Schmied. Romantische Oper in vier Aufzügen. Nach Simrock's.

[3] Bristow JM. What Camelot Means: Women and LGBTQ+ Authors Paving the Way for a More Inclusive Arthuriana through Young Adult Literature. 2021.

[4] Cox DR. The Vision of Robinson's Merlin. Colby Quarterly. 1964; 10(8): 6.

[5] Dobson K. (n.d.). Consciously Creating Camelot.

[6] Edwards JC. Casting, Plotting, and Enchanting: Arthurian Women in Starz's Camelot and the BBC's Merlin. Arthuriana. 2015; 25(1): 57-81.

[7] Falkenhayner N. Merlin versus Misfits: Heroic British youth telefantasy. In Heroes in Contemporary British Culture. Routledge. 2021; 110-134. 
[8] Keen A. (n.d.). On second thoughts, let's not go to Camelot: situating the 'historical Arthur'through casting in King Arthur and The Last Legion. Cinema and Antiquity. 2000-2011.

[9] Liska A. Saint Merlin: Christian Conjunction of Medieval Magicians in Le Morte d'Arthur and Its Romance Tradition. Villanova University. 2021.

[10] Manea D. Evil Nuns and Useless Priests: On the Representation of Christianity in Contemporary Historical Fantasy Television Series. In Religious Narratives in Contemporary Culture . Brill. 2021; 117-136.

[11] Miller AD. The Avuncular Master: The Figure of Merlin and Modern Notions of Meritocratic Education. The Journal of Aesthetic Education. 2019; 53(2): 40-58.

[12] Nygård I. The Arthurian Legend on the small screen: Starz'Camelot and BBC's Merlin. 2013.

[13] Prażuch B. Morgan le Fay and her Portrayals in Selected Medieval Sources and the Miniseries Merlin. 2018.

[14] Tropin T. The relationship between Arthurian tradition and science fiction in Diana Wynne Jones's novel'Hexwood'. Kultura. 2020; 168: 14-27.

[15] WOMACK C. Magician, Man and Manipulator in Camelot. Hero or Villain?: Essays on Dark Protagonists of Television. 2017; 109. 